\title{
MODULAR BAMBOO STRUCTURE DESIGN EXPLORATION WITH DEPLOYABLE CONSTRUCTION SYSTEM
}

\author{
${ }^{1}$ Yosafat Bakti Dwiana. ${ }^{2}$ Anastasia Maurina, S.T., M.T. \\ ${ }^{1}$ Student in the Bachelor's (S-1) Study Program in Architecture \\ at Parahyangan Catholic University \\ 2 Senior lecturer in the Bachelor's (S-1) Study Program in Architecture \\ at Parahyangan Catholic University
}

\begin{abstract}
Deployable structure is a type of structure that can be transformed from a closed configuration to an open configuration. This structure can be assembled and disassembled with ease. This easy construction is a reason why deployable structure is the right structure for after disaster scenario. In emergency, natural resources are needed since it can be found and used easily. Bamboo is a common plant that can be found everywhere in Indonesia.

Research have been done by UNPAR's architecture lecturer regarding deployable structure (deployable spatial and deployable planar) with bamboo as its material. It says that deployable spatial structure has easier and shorter time in instalation than deployable planar structure. Deployable spatial structure has tons of room for development. Some development that can be done is to make deployable structure module to be duplicated in every direction, and to implement self locking mechanism in this structure.

This research is done to find deployable structure module that can be duplicated in every direction, and also implementing self locking mechanism in this structure

Method that used in this research is qualitative by comparing some buildings that implementing deployable system (Resiploy and Triangle Prism) and modular system (Rising Canes and Y-BIO). The comparastion result is opportunity and thread from each building. This result which is opportunity and thread from each building then synthesized to find criteria for deployable structure that can be duplicated in every direction.

Based on the research, it can be concluded that in deployable structure, nut and bolt is needed so that some building element can be rotated to create a movement. In modular building, we need a simple system that can be used in every joint so that building can be duplicated in every way with ease. Reciprocal structure is needed to make a building with self locking mechanism. By simplifying Resiploy's joint and using Rising Canes's modules, we can make a deployable structure that can be duplicated in every way with self locking mechanism
\end{abstract}

Key Words: bamboo structure, deployable, modular, self locking mechanism

\section{EKSPLORASI DESAIN STRUKTUR BAMBU MODULAR DENGAN SISTEM KONSTRUKSI DEPLOYABLE}

\author{
${ }^{1}$ Yosafat Bakti Dwiana. ${ }^{2}$ Anastasia Maurina, S.T., M.T. \\ ${ }^{1}$ Mahasiswi S1 Program Studi Arsitektur Universitas Katolik Parahyangan \\ ${ }^{2}$ Dosen Pembimbing S1 Program Studi Arsitektur Universitas Katolik Parahyangan
}

\begin{abstract}
Abstrak- Struktur bangunan deployable merupakan struktur yang dapat bertransformasi dari konfigurasi tertutup ke konfigurasi terbuka. Struktur deployable dapat dibangun dan dibongkar dengan sangat mudah. Kemudahan pembangunan ini membuat struktur deployable menjadi solusi yang tepat dalam kondisi pasca bencana. Dalam keadaan darurat, material alam sangat dibutuhkan karena mudah ditemukan dan digunakan. Bambu merupakan salah satu tanaman rumput yang banyak dijumpai di Indonesia.
\end{abstract}

\footnotetext{
${ }^{1}$ Corresponding Author: yosafatbakti@yahoo.com
} 
Penelitian mengenai struktur deployable (spatial dan planar) dengan material bambu sudah pernah dilakukan oleh dosen Arsitektur UNPAR. Hasilnya menunjukan bahwa struktur deployable spatial merupakan struktur yang memiliki waktu instalasi di lapangan lebih cepat dan mudah dibandingkan struktur deployable planar. Struktur deployable spatial ini memiliki potensi pengembangan. Potensi pengembangan yang diperlukan adalah kemampuan duplikasi ke berbagai arah pada modul struktur deployable, serta kemampuan struktur deployable untuk dapat mengunci sendiri (self locking mechanism).

Tujuan dari penelitian ini adalah mencari sistem struktur deployable yang dapat diduplikasi ke berbagai arah dengan sistem modular, dan juga dapat mengunci sendiri (self locking mechanism)

Metoda yang digunakan pada penelitian ini adalah kualitatif dengan melakukan komparasi objek studi yang memanfaatkan sistem deployable (Resiploy dan Prisma Segitiga) dan modular (Rising Canes dan Y-BIO). Hasil dari komparasi ini adalah potensi dan kendala dari masing-masing sistem struktur yang kemudian dikaji agar mendapatkan kriteria yang dibutuhkan dalam eksplorasi struktur modular dengan sistem konstruksi deployable.

Berdasarkan penelitian yang sudah dilakukan, diperoleh kesimpulan bahwa pada bangunan deployable, bangunan menggunakan mur dan baut sebagai sambungan utama bangunannya karena kebutuhan bangunan tersebut untuk dapat bergerak. Sedangkan pada bangunan modular, semua bangunan menggunakan sambungan yang sama pada pertemuan unsur bangunan tersebut karena kebutuhan bangunan untuk dapat diduplikasi dengan mudah. Untuk membuat suatu bangunan yang menerapkan sistem penguncian mandiri, dibutuhkan struktur resiprokal dalam bangunan tersebut. Dengan menyederhanakan sambungan pada Resiploy dan memanfaatkan bentuk Rising Canes didapatkan struktur bangunan yang dapat memenuhi kriteria struktur deployable, modular, dan sistem penguncian mandiri.

Kata Kunci: struktur bambu, deployable, modular, sistem penguncian mandiri

\section{PENDAHULUAN}

Struktur deployable merupakan sebuah struktur yang memiliki kemampuan untuk bertransformasi dari konfigurasi tertutup (kompak) ke konfigurasi terbuka, di mana pada konfigurasi terbuka ini struktur tersebut memenuhi persyaratan struktur, yaitu: kuat, kaku, dan stabil. Pencapaian kemampuan struktur untuk dideploy terkadang melalui sebuah perancangan dan pendetailan yang kompeks untuk dapat mencapai potensinya dari aspek konfigurasi tertutup (kompak), transportabilitas, instalasi dan juga pembongkaran (Grosso \& Basso, 2013). Struktur ini memiliki beragam keuntungan, salah satunya adalah kemampuannya untuk dapat dibangun dengan cepat karena memiliki sistem sambungan tertentu.

Kehadiran struktur deployable ini membuka berbagai kemungkinan pengembangan khususnya di dunia arsitektur. Terdapat beberapa waktu di mana dibutuhkan bangunan semi permanen yang dapat dibangun dengan cepat dan mudah, seperti pada saat setelah terjadinya bencana alam di mana masyarakat membutuhkan tempat tinggal sementara yang cepat dalam pembangunannya. Dengan adanya struktur ini dapat memungkinkan pengerjaan bangunan dengan waktu yang relatif singkat dan mudah sehingga bangunan tersebut bisa langsung digunakan. Selain untuk bangunan semi permanen, sistem deployable ini juga dapat dikembangkan untuk menjadi bangunan permanen dengan penambahan beberapa komponen struktur.

Dari segi arsitektur, struktur deployable dapat menjadi struktur dari sebuah tempat bernaung, entah itu rumah, ataupun fungsi lain. Seperti yang telah ditulis diatas, bahwa struktur deployable ini dapat menjadi solusi kebutuhan tempat tinggal pada keadaan pasca bencana. Kerusakan massal hunian dan fasilitas publik akibat bencana alam dapat memakan korban ribuan unit. Hunian adalah kebutuhan pokok manusia, sehingga harus sesegera mungkin dikembalikan.

Kebutuhan akan hunian darurat ini tentunya harus didukung dengan ketersediaan material untuk pembuatannya. Bambu merupakan salah satu material alam yang mudah ditemui di Indonesia. Terdapat sekitar 60 jenis bambu di Indonesia menurut Dansfield dalam bukunya yang berjudul Plant Resources of South Asia No.7. Keberagaman jenis bambu di 
Indonesia menjadi sebuah kesempatan untuk dilakukannya pengamatan dan pengolahan bambu menjadi material bangunan.

Bambu merupakan material yang berkelanjutan (sustainable) yang dapat tumbuh dengan sangat cepat, berbeda dengan material lain seperti kayu yang pertumbuhannya cenderung lambat. Pemanfaatan bambu sebagai bahan bangunan pun sangatlah maksimal tidak seperti kayu yang menghasilkan banyak sisa untuk mendapat bentuk yang diinginkan. Penggunaan bambu cenderung utuh sehingga material ini dianggap unik dengan bentuk dan ukuran yang berbeda setiap batangnya.

Beberapa studi mengenai desain struktur deployable dengan material bambu sudah pernah dilakukan baik oleh mahasiswa maupun dosen UNPAR yang menghasilkan beberapa jenis struktur rangka, diantaranya adalah struktur rangka "Resiploy" (Resiprokal dan Deployable) yang merupakan hasil Skripsi karya Bernadette Sudira pada tahun 2016, dan juga struktur rangka "Prisma Segitiga" yang merupakan hasil pengembangan dari "Resiploy" pada tugas mahasiswa Arsitektur UNPAR di mata kuliah Struktur Konstruksi Bangunan Bentang Lebar (SKBBL) dibawah bimbingan Anastasia Maurina, S.T., M.T., M. Budianastas P, S.T., M.T., dan Laurenia Carissa, S.T., M.T. pada tahun 2017. Kedua bangunan ini merupakan contoh struktur deployable dengan material bambu, di mana bangunan ini memiliki ruang yang terdiri atas modul-modul yang dapat dilipat dan dibuka dengan mudah.

Kedua bangunan ini (Resiploy dan Prisma Segitiga) kemudian dikaji oleh Anastasia Maurina, S.T., M.T., M. Budianastas P, S.T., M.T., dan Laurenia Carissa, S.T., M.T. pada tahun 2017 dalam penelitian yang berjudul Eksplorasi Struktur Bambu Dengan Konstruksi 'Deployable'. Pada penelitian ini disimpulkan bahwa struktur bambu deployable spatial memiliki banyak potensi untuk dikembangkan. Kemampuan struktur ini untuk dibangun dengan cepat merupakan salah satu alasan dipilihnya sistem ini sebagai bangunan semi permanen pada pengungsian. Tentunya kedua bangunan ini juga memiliki potensi dan kendala tersendiri yang perlu diperhatikan.

Pada Resiploy, modul yang dibuat tidak memiliki variasi di dalam bentuk dan dimensi modul sehingga tidak dapat didupklikasi ke berbagai arah. Sedangkan pada Prisma Segitiga modul memiliki beberapa variasi dan dimensi sehingga dapat diduplikasi. Namun duplikasi modul struktur ini hanya bisa dilakukan dengan konfigurasi linear (1 arah). Kedua bangunan ini membutuhkan keahlian lebih dalam pembuatan modulnya, berat dan ukurannya pun cukup besar sehingga sulit untuk dipindahkan.

Perancangan sistem struktur yang dapat diduplikasi dikenal juga dengan sistem modular, di mana suatu bangunan dibagi-bagi ke dalam bagian yang lebih kecil (modul) yang dapat dibuat sendiri dan kemudian digunakan dalam sebuah sistem. Keuntungan sistem modular ini adalah keleluasaan dalam desain di mana kita dapat menambah dan mengurangi modul sesuai kebutuhan dan juga dapat berkurangnya biaya produksi dikarenakan adanya keseragaman dalam produk yang dihasilkan.

Salah satu bangunan dengan sistem struktur bambu yang menerapkan sistem modular adalah 'Rising Canes'. Bangunan ini merupakan salah satu rancangan dari studio arsitektur asal Beijing yang bernama Penda. Dalam acara Beijing Design Week tahun 2015, Penda berkesempatan untuk membangun struktur ini dalam sebuah instalasi. Desain bangunan ini memanfaatkan material alami yang mudah didapat sebagai strukturnya. Fokus dari rancangan ini adalah untuk membuat bangunan yang tidak memberikan dampak pada lingkungan, maupun bambu itu sendiri. Penggunaan bambu pada bangunan ini merupakan bambu yang telah digunakan sebagai scaffolding pada saat pembangunan bangunan lain. Bangunan ini memilki bentuk yang unik sehingga memiliki variasi dimensi dan bentuk modul serta dapat dikonfigurasi modulnya. 
Selain 'Rising Canes', terdapat contoh bangunan lain dari sistem modular. Tetapi bangunan ini berbeda dengan 'Rising Canes' karena sistem ini memanfaatkan batang besi sebagai bahan utama dalam perancangan. Bangunan yang dimaksud adalah 'Y-BIO' dari Archinoma. Bangunan ini menggunakan batang-batang besi yang dirangkai untuk menghasilkan bangunan semi permanen. Setiap batang besi memiliki titik sambung yang kemudian disusun dan diikat hingga membentuk suatu konfigurasi tertentu. 'Y-BIO' yang sudah terbangun terdapat di sisi laut Crimea, Eropa.

Untuk dapat membuat struktur bambu deployable spatial yang dapat diduplikasi ke berbagai arah, maka dirumuskan beberapa masalah sebagai berikut:

- Apakah potensi dan kendala dari sistem deployable spatial pada objek studi Resiploy dan Prisma Segitiga?

- Bagaimana sistem modular diterapkan pada sistem struktur dan konstruksi bambu dari objek studi Rising Canes dan Y-BIO?

- Bagaimana penggabungan desain struktur bambu modular dengan sistem konstruksi deployable hasil perpaduan dari sistem deployable spatial dan sistem modular?

Tujuan dari penelitian ini yaitu mengembangkan desain struktur bambu deployable spatial agar dapat diduplikasi ke berbagai arah. Sistem struktur deployable spatial ini dibuat modular agar konfigurasi modulnya lebih variatif sesuai dengan kebutuhan pengguna.

\section{KAJIAN TEORI}

\subsection{OBJEK STUDI}

Resiploy merupakan singkatan dari resiprokal dan deployable. Struktur ini merupakan hasil dari riset (Skripsi Arsitektur) Bernadette Sudira pada tahun 2016. Banguna ini merupakan gabungan antara Bangunan Geladak Lipat dan Bamboo Community Hall. Bentuk bangunan merupakan segi enam karena memiliki potensi untuk dibuat modular secara horizontal, dan juga berpotensi untuk dibentuk secara vertikal.

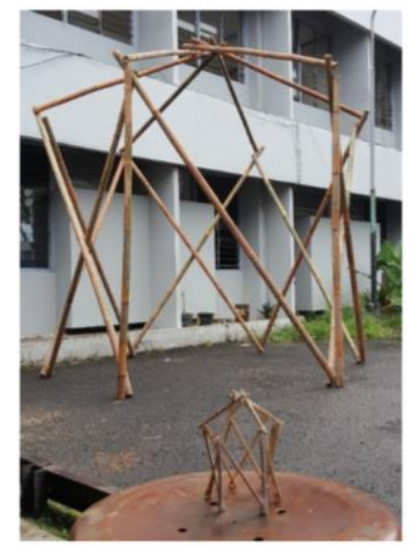

Figur 1 Struktur Rangka "Resiploy"

(Sumber: Sudira, Bernadette. (2016). Eksplorasi Konstruksi Bambu Dengan Sistem Deployable. Skripsi tidak diterbitkan. Bandung: Universitas Katolik Parahyangan)

Bangunan resiploy memiliki satu kesatuan modul struktur. Sistem engsel yang bekerja pada tiap-tiap batang komponen bangunan berintegrasi menjadi satu modul yang padu. Modul yang berintegrasi tersebut adalah modul badan bangunan dan modul rangka atap. Badan bangunan menggunakan sistem bar spasial dengan sedikit modifikasi pada salah satu sistem 
salah satu sisi bangunan sebagai entrance dan atap bangunan menggunakan sistem resoprokal. Sistem bar spasial dan sistem resiprokal ini saling berintegrasi.

Prisma Segitiga merupakan pengembangan struktur resiploy dengan sistem SLE (Scissor Like Element) - spasial, di mana tujuan utama dari pengembangan struktur ini adalah meningkatkan variasi bentuk dan dimensi serta mempermudah prefabrikasi modul. Struktur ini merupakan hasil pengembangan tugas mahasiswa di mata kuliah Struktur Konstruksi Bangunan Bentang Lebar dibawah bimbingan Anastasia Maurina, S.T., M.T., M. Budianastas P, S.T., M.T., dan Laurenia Carissa, S.T., M.T. Prototype dibangun pada tahun 2017 di UNPAR sebagai uji coba mekanismenya.

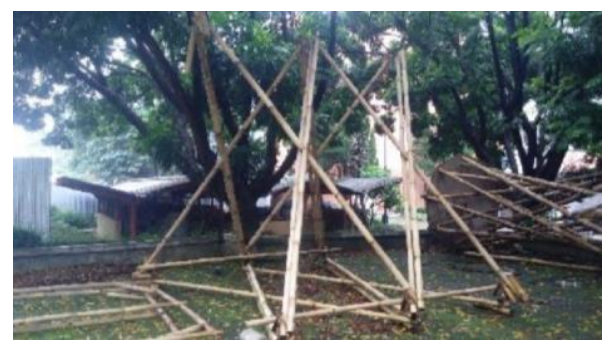

Figur 2 Struktur Rangka "Prisma Segitiga"

(Sumber: Maurina, A., Budianastas, P., \& Carissa. (2017). Eksplorasi Struktur Bambu Dengan Konstruksi 'Deployable'. Bandung: Universitas Katolik Parahyangan)

Denah bangunan berbentuk persegi panjang dengan lebar bangunan 1,5-2,6 $\mathrm{m}$ dengan panjang 3-6 m sehingga luas banguna berkisar 7,8-10 $\mathrm{m}^{2}$. Ketinggian ruang adalah 2,33,2 m tanpa adanya kemungkinan untuk penambahan mezzanine. Bangunan ini berkapasitas sekitar $6-8$ orang dengan asumsi setiap orang membutuhkan luas $1,2 \mathrm{~m}^{2}$.

Rising Canes adalah bangunan ciptaan Penda yang merupakan studio arsitektur yang berasal dari Beijing. Mereka percaya bahwa struktur yang terbuat dari pertemuan tongkat bambu horizontal dan vertikal dapat digunakan sebagai infrastruktur kota pada tahun 2023. Mereka membuat sistem struktur modular dari bambu yang sangat unik. Struktur ini memanfaatkan sistem modular dalam desainnya sehinggi memiliki kemampuan untuk direpetisi baik secara horizontal maupun vertikal.

Struktur bangunan terinspirasi dari bangunan tradisional bangsa Indian, yang bernama Tipis yang tidak meninggalkan kerusakan baik pada tapak, maupun material itu sendiri dikarenakan sambungan bangunan ini diikat dengan tali, sehingga bangunan menjadi mudah untuk dibangun, dibongkar, dan dibawa.

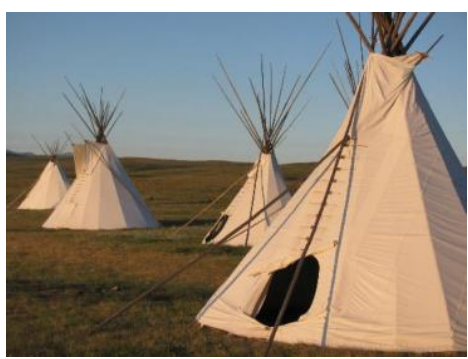

Figur 3 Teepee

(Sumber : tripadvisor.com)

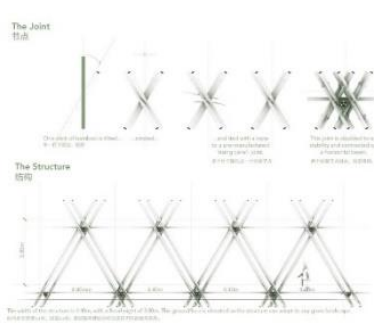

Figur 4 Sambungan dalam Rising Canes

(Sumber : home-of-penda.com)

Y-BIO adalah sebuah bangunan yang memanfaatkan sistem archinoma. Archinoma adalah sebuah sistem modular yang menciptakan objek arsitektur yang dapat berubah dalam berbagai ukuran, bentuk, dan rupa. Inti dari bangunan archinoma adalah penggunaan batang 
baja yang disambungkan ke sambungan Shelest. Ide ini memungkinkan tergabungnya 14 balok dalam satu sambungan hanya dengan peralatan sederhana. Keuntungan dari sistem modular ini adalah: Pembuatan rumah dalam berbagai ukuran dengan kakuatan maksimal, bersahabat dengan alam karena tidak menggunakan pondasi, serta untuk membangun objek archinoma tidak membutuhkan pengetahuan khusus dalam bidang apapun kita hanya membutuhkan peralatan sederhana.

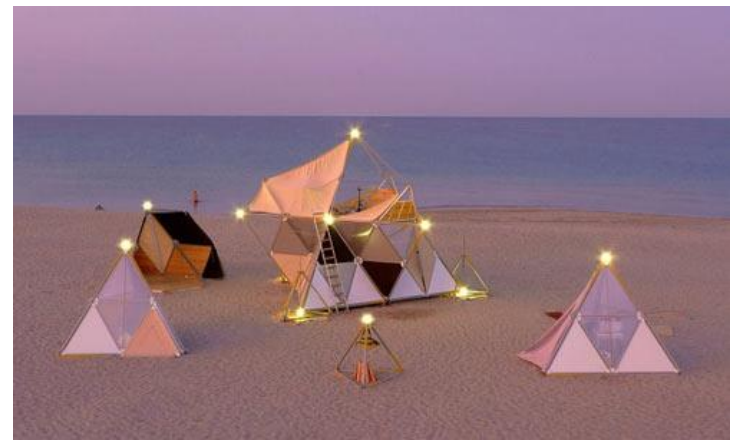

Figur 5 Y-BIO, Karya Archinoma

(Sumber : design-milk.com)

\section{METODA PENELITIAN}

Penelitian menggunakan metoda komparatif atau perbandingan yang dimaksudkan untuk membandingkan masing-masing objek studi yang dibahas agar mendapat potensi dan kendala dari masing-masing objek studi. Hasil dari komparasi ini kemudian disintesiskan untuk menemukan kriteria sistem struktur yang tepat untuk struktur bangunan deployable dengan sistem konstruksi modular.

Selain itu, eksplorasi pada objek studi melalui maket juga akan dilakukan guna melihat secara langsung bagaimana sebuah sistem dapat bekerja. Eksplorasi melalui eksperimen berupa maket digunakan untuk mencoba berbagai macam gabungan sistem sehingga didapatkan sistem terbaik yang memenuhi kriteria.

\section{ANALISA}

\subsection{KOMPARASI STRUKTUR DEPLOYABLE DAN MODULAR PADA OBJEK STUDI}

Pada bangunan Resiploy, denah bangunan berbentuk segi enam dengan bentuk trapesium. Resiploy memiliki ukuran yang tidak dapat dirubah karena adanya sistem penguncian pada bangunan. Ketika bangunan tidak sesuai dengan ukuran yang ada, bangunan tidak akan terkunci sehingga mengurangi kekuatan bangunan.

Sedangkan pada Prisma Segitiga, denahnya persegi empat dengan bentuk segitiga menyerupai piramida yang saling menimpa. Ukuran dari Prisma Segitiga dapat diatur sesuai dengan kebutuhan karena tidak adanya sistem penguncian mandiri pada bangunan. Semakin lebar bangunan, semakin rendah ketinggiannya.

Pada Rising Canes, denah persegi empat dengan bentuk segitiga. Bangunan ini pada konsep awalnya merupakan kolom bambu yang mencakup 2 lantai, sehingga ukurannya cukup besar jika dibandingkan bangunan lain. Ukuran dari bangunan ini dapat dirubah sesuai dengan kebutuhan. Sama seperti Prisma Segitiga, semakin rendah bangunan, semakin luas juga bangunannya. 
Sedangkan pada Y-BIO, bangunan merupakan pencampuran dari beberapa batang yang diikat. Batang yang digunakan berbahan dasar metal, dengan sambungan yang juga metal. Ukuran dari bangunan ini terbentuk dari pertemuan batang yang disusun sesuai kebutuhan.

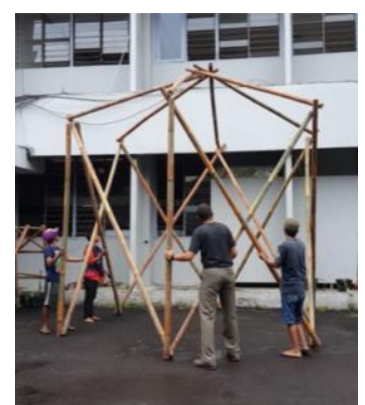

Figur 6 Resiploy

(Sumber: Sudira, Bernadette. 2016. Eksplorasi Konstruksi Bambu Dengan Sistem Deployable. Skripsi Prodi Arsitektur. UNPAR)

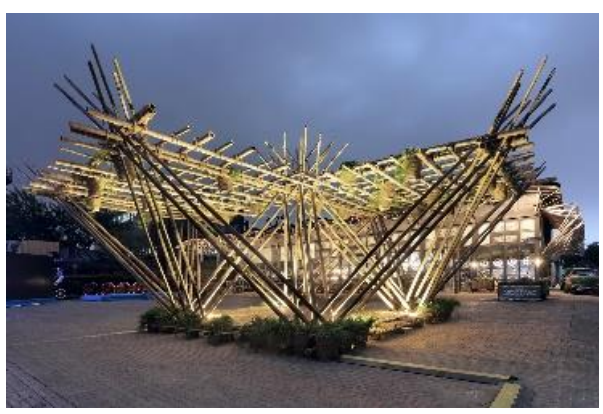

Figur 8 Rising Canes

(Sumber : behance.com)

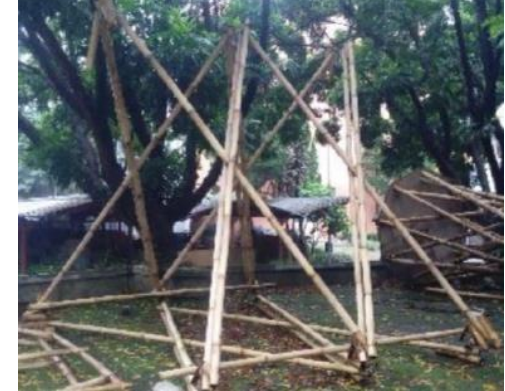

Figur 7 Prisma Segitiga

(Sumber: Maurina, Anastasia. 2017. Eksplorasi Konstruksi Bambu Dengan Konstruksi 'Deployable')

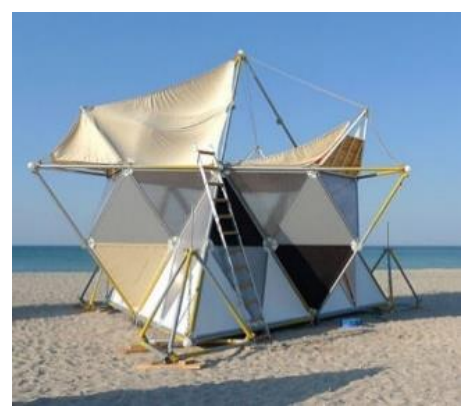

Figur 9 Y-BIO

(Sumber : desgin-milk.com)

Resiploy memiliki 2 macam sambungan yang memungkinkan terjadinya deployable. Pada bagian atap bangunan, terdapat sambungan lingkaran besi sebagai sistem pengunci mandiri pada bangunan. Dengan sambungan ini, setiap batang bambu dalam bangunan, khususnya pada bagian atap, dapat saling menopang. Kemampuan saling menopang ini bernama resiprokal. Kemampuan resiprokal ini memungkinkan terjadinya deployable pada Resiploy. Selain itu, sambungan SLE (Scissor Like Element) yang berada pada badan bangunan juga membuat bangunan ini dapat dilipat.

Kemampuan Prisma Segitiga untuk dapat dilipat dan dibuka tercapai karena terdapat sambungan SLE. Mengingat bahwa Prisma Segitiga adalah pengembangan dari Resiploy, maka sambungan pada Prisma Segitiga pun hampir sama dengan Resiploy. Sambungan SLE pada bangunan ini membuat bangunan dapat dilipat (deployable).

Sedangkan pada Rising Canes, bangunan tidak dapat di-deploy karena tidak mempunyai sambungan yang memadai untuk terjadinya pergerakan pada elemen bangunan. Ketidakmampuan untuk di-deploy inilah yang membuat bangunan ini tidak dapat dilakukan sebelumnya (Prefabrikasi), sehingga pengerjaan bangunan harus pada lokasi.

Kemampuan deployable pada Y-BIO dipengaruhi oleh batang yang digunakan, tergantung dari kebutuhan pengguna. Pada dasarnya Y-BIO merupakan modul struktur yang sangat fleksibel, di mana tiap batang dapat dipasang dan dilepas sesuai dengan kebutuhan. Sehingga dapat dibilang bahwa Y-BIO dapat di-deploy sesuai kebutuhan pengguna, meskipun deployable pada Y-BIO merupakan pembokaran dan pemasangan kembali. 


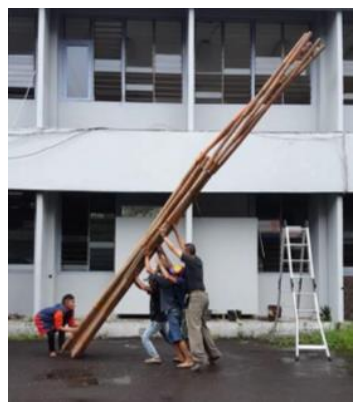

Figur 10 Portabilitas Resiploy

(Sumber: Dokumentasi Bernadette Sudira)

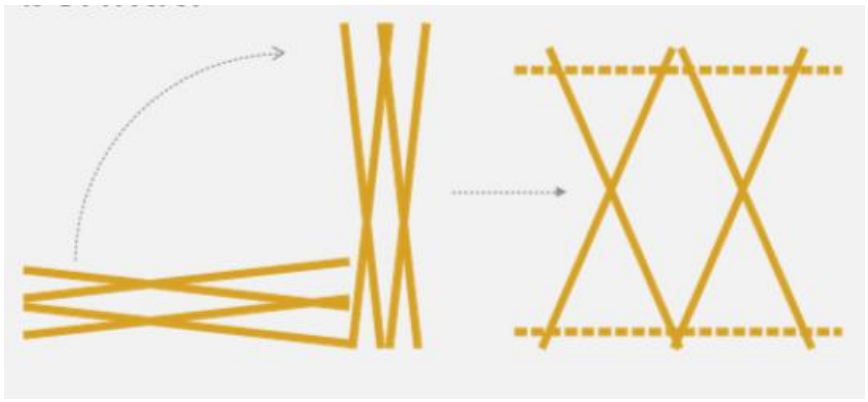

Figur 11 Portabilitas Prisma Segitiga

Sumber: Maurina, A., Budianastas, P., \& Carissa. (2017). Eksplorasi Struktur Bambu Dengan Konstruksi 'Deployable'. Bandung: Universitas Katolik Parahyangan)

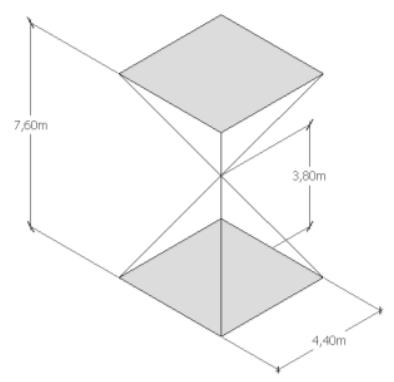

Figur 12 Ukuran Rising Canes

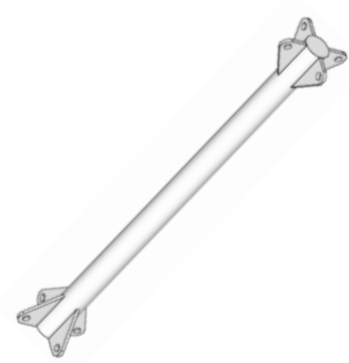

Figur 13 Batang Y-BIO

Resiploy tidak dapat diduplikasi dikarenakan seluruh selubung bangunan ini memiliki penutup sehingga menghasilkan konfigurasi tertutup. Tidak adanya sambungan yang memadai juga menjadi faktor ketidakmampuan bangunan ini untuk diduplikasi. Meskipun tidak dapat direpetisi, bentuk segienam pada Resiploy sebenarnya merupakan potensi repetisi karena dapat disambung ke berbagai arah.

Kemampuan duplikasi pada Prisma Segitiga dapat dilakukan secara linear 1 arah karena terdapat area terbuka pada 2 muka bangunan. Konfigurasi linear 2 arah tidak dapat dilakukan karena pada muka bangunan yang lain tertutup oleh elemen penguat bangunan. Pada bangunan ini terdapat sambungan SLE di pertemuan segitiga dan sambungan besi segitiga pada sambungan bambu yang memungkinkan dilakukannya duplikasi 1 arah.

Pada Rising Canes, duplikasi dapat dilakukan ke semua arah dikarenakan bentuknya yang terbuka dan karena konstruksi ini menghasilkan kolom yang dapat berdiri sendiri, sehingga tidak terdapat dinding atau elemen penutup yang menghalangi untuk terjadinya duplikasi. Duplikasi pada bangunan juga dapat terjadi karena digunakannya sambungan yang sangat sederhana (ikatan ijuk) yang diulang ditiap pertemuan bambu.

Duplikasi pada Y-BIO dapat dilakukan berkat sambungannya yang mudah dan sistem archinoma yang diterapkan pada bangunan ini. Y-BIO dapat diduplikasi ke segala arah selama sambungan metalnya masih dapat disambung. Keterbatasan hanya terdapat pada ruang sambungan. 


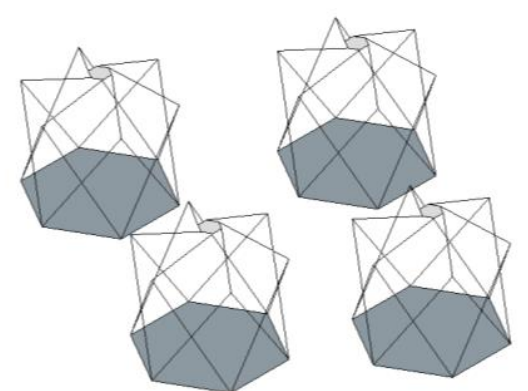

Figur 14 Resiploy Tidak Mampu Duplikasi

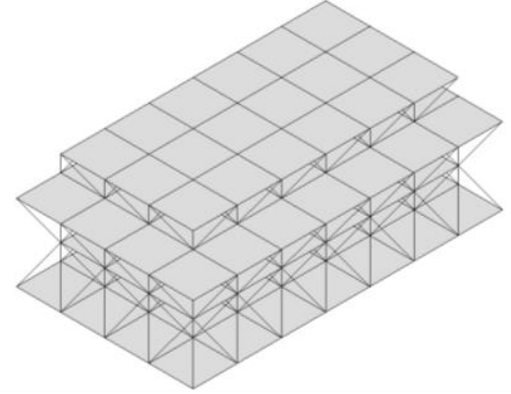

Figur 16 Kemampuan Duplikasi Rising Canes

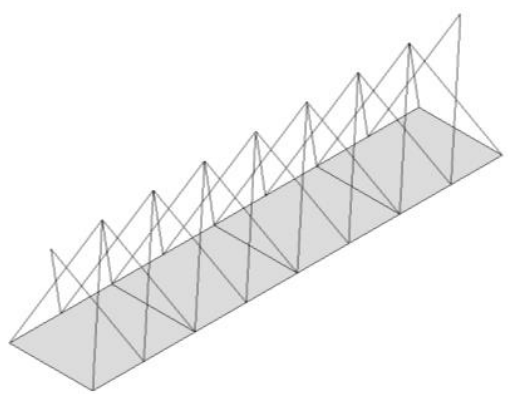

Figur 15 Kemampuan Duplikasi Prisma Segitiga

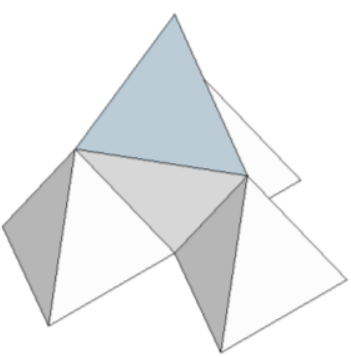

Figur 17 Kemampuan Duplikasi Y-BIO

Stabilitas pada Resiploy dapat dicapai berkat adanya sambungan besi pada bagian atap bangunan. Resiploy dapat semakin stabil ketika menerima beban pada atap bangunan. Hal ini dapat terjadi karena adanya kemampuan resiprokal pada atap bangunan. Elemen pengaku tidak dibutuhkan pada Resiploy karena bangunan dapat berdiri sendiri dengan struktur resiprokal

Prisma Segitiga dapat stabil karena terdapat elemen pengaku pada bangunan. Elemen pengaku sangat dibutuhkan oleh Prisma Segitiga karena tidak mungkin bangunan ini dapat berdiri kokoh tanpa adanya elemen pengaku. Terdapat 3 balok yang dibutuhkan untuk mengunci bangunan ini. 3 balok itu terdiri dari 1 balok pada bagian atas dan 2 balok pada bagian samping bawah.

Mengingat Rising Canes merupakan perpaduan kolom, maka tentunya stabilitas bangunan dicapai dengan bantuan elemen pengaku yang dibutuhkan untuk menguatkan bangunan. Namun, penguncian hanya dibutuhkan ketika struktur direpetisi membentuk ruang tertentu. Karena ketika berdiri sendiri, tidak butuh penguncian mandiri. Pada saat bangunan berdiri sendiri, sebenarnya bangunan ini memiliki kemampuan resiprokal di mana keempat batang bambu saling menumpu satu sama sehingga tercapai keadaan stabil.

Pada Y-BIO selutuh bangunan terbuat dari batang yang diikat satu sama lain, sehingga semuanya merupakan elemen pengaku. Stabilitas pada Y-BIO dicapai ketika bangunan terbentuk secara utuh, dan seluruh batang saling mengunci.

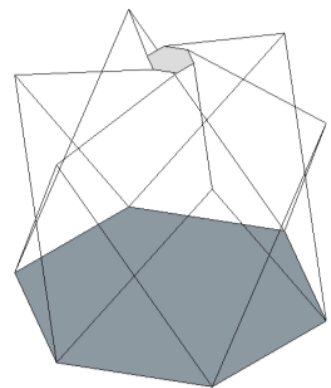

Figur 18 Resiploy dengan Penguncian Mandiri

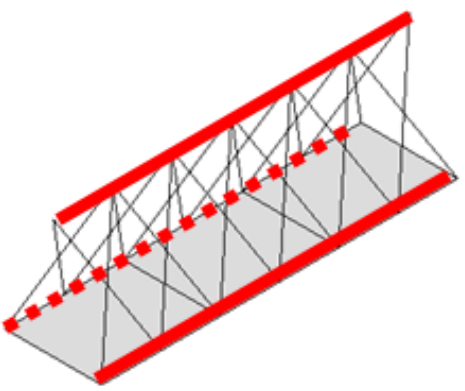

Figur 19 Elemen Pengaku Prisma Segitiga 


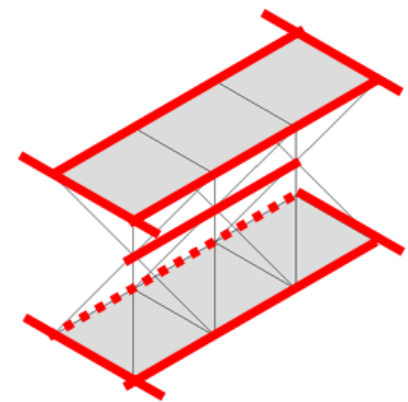

Figur 20 Elemen Pengaku Rising Canes

Pada Resiploy terdapat 2 jenis sambungan. Sambungan dengan mur baut pada Resiploy memungkinkan terjadinya lipatan pada bangunan. Namun gerakan yang terjadi hanya 1 , yaitu gerakan memutar pada porosnya di mur baut ini. Gerakan menyerupai gunting tercipta karena menggunakan sambungan ini. Sambungan lainnya adalah adanya lingkaran besi pada puncak bangunan. Lingkaran ini merupakan kunci berdirinya struktur ini. Dengan adanya lingkaran ini, elemen konstruksi akan saling mengunci dan menumpu satu kepada yang lainnya yang dinamakan resiprokal. Namun, lingkaran ini tidak dapat dibuat sembarangan, sehingga cukup sulit untuk dibuat.

Sambungan pada Prisma Segitiga terdiri dari mur baut (SLE) dan segitiga besi puncak. Sama seperti Resiploy, sambungan mur baut memungkinkan terjadinya lipatan dan pergerakan dalam bangunan. Sedangkan segitiga besi pada sudut bangunan menjadi pusat pergerakan lipatan pada bangunan. Karena sulitnya membuat sambungan untuk gerakan diagonal dengan mur baut biasa, maka dibutuhkan segitiga ini sebagai poros putaran bambu. Selain itu, penggunaan sambungan ini juga memungkinkan terjadinya duplikasi pada bangunan, karena kedua sambungan ini dapat diulang terus pada 1 arah.

Pada Rising Canes hanya terdapat 1 sambungan yang adalah sambungan ikatan dengan ijuk. Sambungan dengan ikatan memungkinkan terjadinya repetisi modul kesemua arah, karena pertemuan modul dikuatkan dengan ikatan. Pertemuan modul akan menghasilkan sambungan yang sama dengan sambungan tengah modul. Namun sambungan ini tentunya tidak memungkinkan untuk terjadinya gerakan seperti dengan mur baut.

Sedangkan pada Y-BIO sambungannya sama seperti Rising Canes berupa ikatan, namun yang membedakannya adalah material sambungannya. Pada Rising Canes sambungan menggunakan ijuk, sedangkan Y-BIO menggunakan material lain. Y-BIO juga memanfaatkan area sambungan yang telah diciptakan sebelumnya sehingga pengikatan lebih mudah untuk dilakukan, tidak seperti Rising Canes yang ikatannya tidak tersedia area khusus.

Untuk membuat bangunan deployable kita membutuhkan sambungan berupa mur baut yang memungkinkan terjadinya lipatan pada bangunan, sedangkan untuk membuat bangunan modular, kita membutuhkan sambungan berupa ikatan yang sejenis dengan sambungan pada modul. Pertemuan antar modul disambung dengan ikatan yang sama dengan ikatan pada modul yang digunakan. 


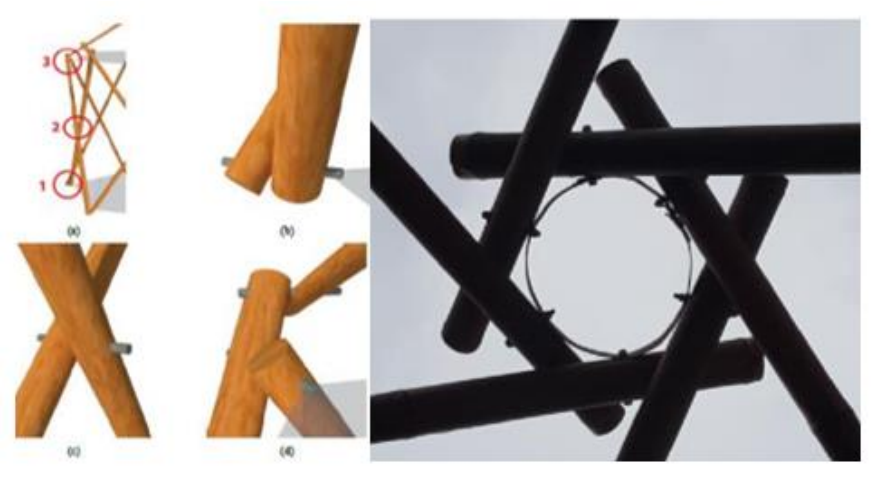

Figur 21 Sambungan Pada Resiploy

(Sumber: Sudira, Bernadette. 2016. Eksplorasi Konstruksi Bambu dengan Sistem Deployable. Skripsi Prodi Arsitektur. UNPAR)

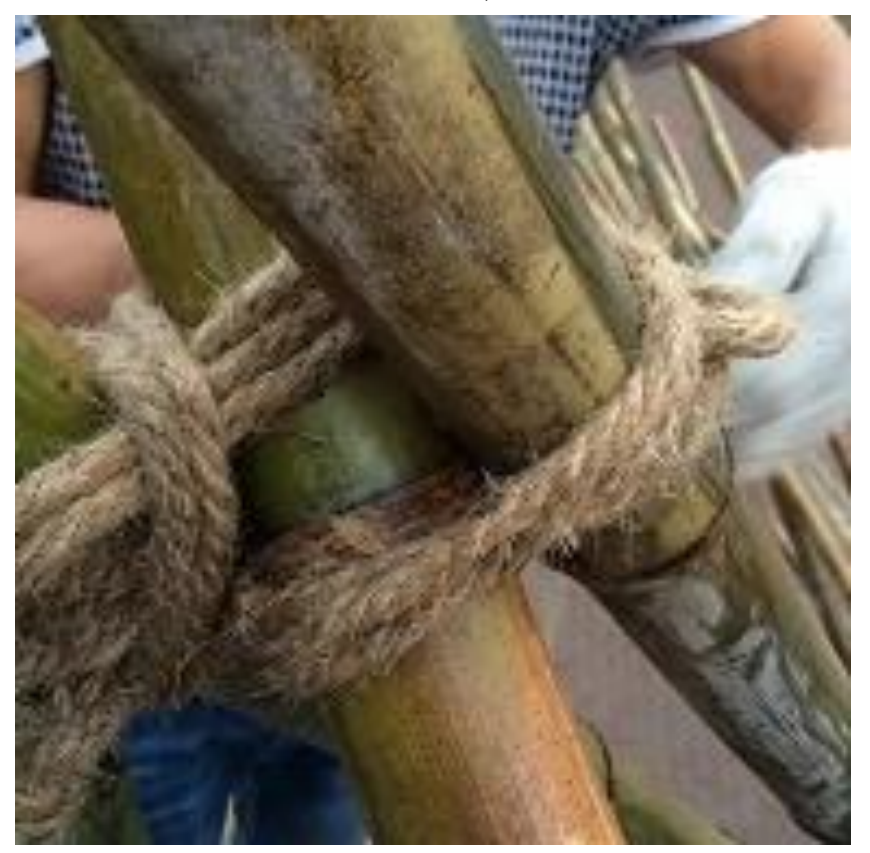

Figur 23 Sambungan Ikatan Ijuk Rising Canes (Sumber : behance.com)

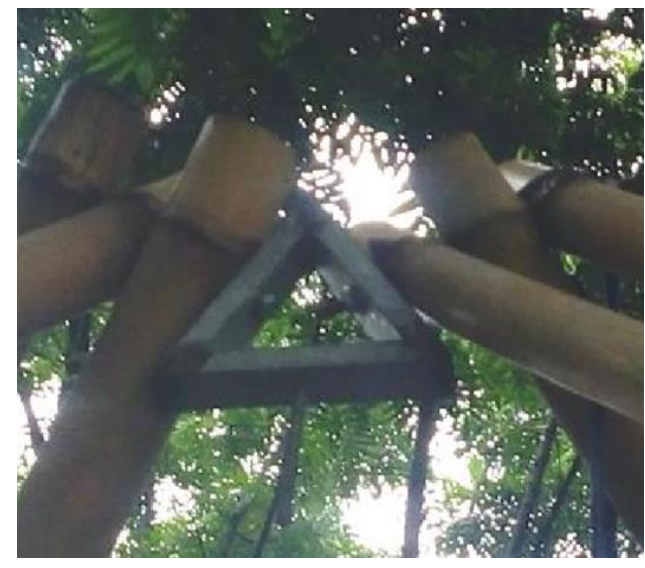

Figur 22 Sambungan Pada Prisma Segitiga (Sumber : Maurina, Anastasia. 2017. Eksplorasi Struktur Bambu dengan Konstruksi 'Deployable'. UNPAR)

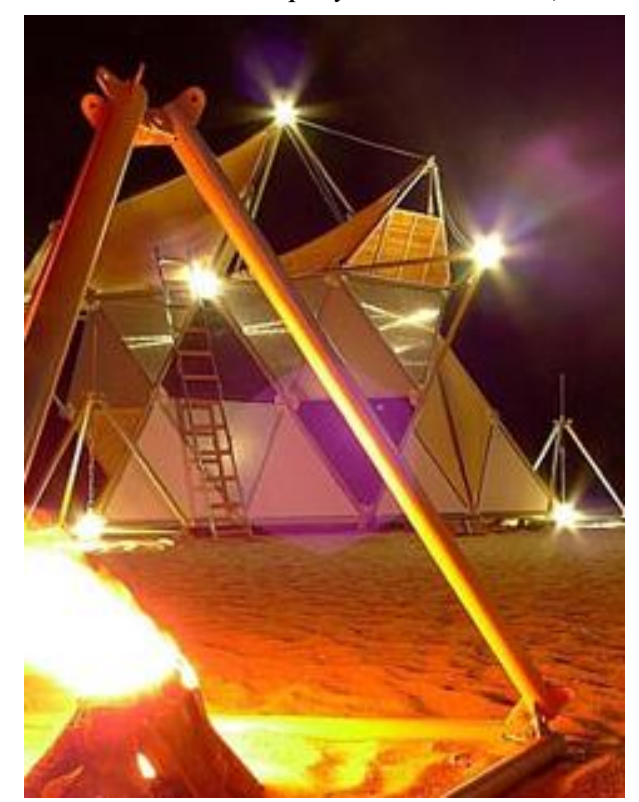

Figur 24 Sambungan Antar Batang Y-BIO (Sumber : design-milk.com)

Pondasi tidak dibutuhkan untuk setiap bangunan dikarenakan terdapat cukup penopang yang menempel tanah dari setiap bangunan. Lokasi penopang inipun menentukan kebutuhan pondasi. Pondasi dapat ditambahkan untuk menambah kekuatan dari bangunan, atau jika dihadapkan pada kondisi alas tertentu. 
Tabel 1 Potensi dan Kendala dari Objek Studi

\begin{tabular}{|l|l|l|}
\hline Objek Studi & Potensi & Kendala \\
\hline Resiploy & $\begin{array}{l}\text { Pencapaian stabilitas dicapai } \\
\text { karena adanya sambungan yang } \\
\text { mendukung terciptanya struktur } \\
\text { resiprokal }\end{array}$ & $\begin{array}{l}\text { Tidak adanya kemampuan duplikasi } \\
\text { karena muka bangunan yang } \\
\text { tertutup dan tidak adanya } \\
\text { sambungan yang memadai }\end{array}$ \\
\cline { 2 - 3 } & $\begin{array}{l}\text { Area guna bangunan luas karena } \\
\text { tidak adanya sudut lancip pada alas } \\
\text { bangunan }\end{array}$ & \\
\hline Prisma Segitiga & $\begin{array}{l}\text { Bangunan mampu diduplikasi 1 } \\
\text { arah berkat muka 2 bangunan yang } \\
\text { terbuka }\end{array}$ & $\begin{array}{l}\text { Ukuran masih cukup besar pada } \\
\text { saat terlipat karena sambungan } \\
\text { yang diterapkan tidak dapat tertutup } \\
\text { dengan rapat }\end{array}$ \\
\cline { 2 - 3 } & $\begin{array}{l}\text { Ukuran bangunan dapat diatur } \\
\text { sesuai kebutuhan karena tidak } \\
\text { adanya sistem penguncian mandiri } \\
\text { pada bangunan }\end{array}$ & $\begin{array}{l}\text { Dibutuhkan elemen pengaku untuk } \\
\text { mencapai stabilitas }\end{array}$ \\
\hline Rising Canes & $\begin{array}{l}\text { Bangunan dapat diduplikasi ke } \\
\text { berbagai arah berkat sambungan } \\
\text { pada tiap pertemuan bambu yang } \\
\text { sama }\end{array}$ & $\begin{array}{l}\text { Tidak dapat dideploy karena tidak } \\
\text { adanya sambungan yang } \\
\text { memungkinkan untuk terjadinya } \\
\text { pergerakan pada bangunan }\end{array}$ \\
\cline { 2 - 3 } & $\begin{array}{l}\text { Bambu yang dibutuhkan sedikit } \\
\text { dengan pengerjaan yang sederhana }\end{array}$ & \\
\hline Y-BIO & \begin{tabular}{l} 
Dapat direpetisi ke segala arah \\
karena sistem sambungan yang \\
sama di tiap pertemuan batang \\
\cline { 2 - 3 } \\
kentuk dapat dirubah sesuai \\
yang sangat fleksibel
\end{tabular} & \\
\hline & & \\
\hline
\end{tabular}

Dari hasil analisa diatas, penulis menganalisa kembali potensi dan kendala yang menjadi alasan suatu bangunan dapat menjadi struktur deployable dan struktur modular dan mengapa suatu bangunan tidak dapat di deploy atau tidak dapat diduplikasi. Hasil analisa ini menghasilkan kriteria. Kriteria yang dimaksud adalah kriteria suatu bangunan yang harus dipenuhi agar suatu sistem struktur dapat bekerja. Dari hasil analisa potensi dan kendala, maka dapat ditarik kesimpulan bahwa untuk merancang struktur modular dengan sistem konstruksi deployable dibutuhkan beberapa kriteria, yaitu:

- Sambungan yang dapat membuat elemen bangunan bergerak (memiliki poros putaran) agar mampu di-deploy

- Pengulangan sambungan di tiap pertemuan elemen agar dapat diduplikasi

- Merupakan struktur resiprokal agar dalam bangunan terdapat sistem penguncian mandiri

\subsection{EKSPLORASI KONSTRUKSI BAMBU}

"Resiploy" rancangan Bernadette Sudira dan "Rising Canes" rancangan Penda merupakan sumber ide dari bangunan yang akan dirancang ini karena kriteria yang dibutuhkan dari struktur deployable dan struktur modular dirasa sangat tercermin dalam kedua bangunan ini. Kemampuan Resiploy yang memiliki sistem penguncian mandiri dan kemampuannya untuk dapat dilipat dengan rapat menjadi alasan bangunan ini dipilih menjadi contoh struktur deployable. Sedangkan kemampuan Rising Canes untuk diduplikasi ke berbagai arah dengan material bambu merupakan alasan dipilihnya bangunan ini sebagai contoh struktur modular.

Sistem penguncian mandiri pada bangunan resiploy terdapat pada sambungan atap bangunan ini. Lingkaran besi ditempatkan pada atap bangunan agar batang bambu pada bagian 
atap ini saling menumpu satu sama lain, sehingga tercipta struktur resiprokal. Dengan adanya lingkaran besi ini, bangunan resiploy tidak lagi membutuhkan unsur pengaku. Sedangkan kemampuan bangunan untuk dapat di deploy didapat dari sambungan pada bangunan ini. Pada bagian badan bangunan, sambungan yang ada adalah SLE dan juga sambungan semacam piston di bagian area masuk. Sedangkan pada atap bangunan, lingkaran besi menjadi sambungan yang memungkinkan terjadinya pergerakan memutar dengan poros di sekitar lingkaran ini. Lingkaran besi ini juga menjadi pengunci pergerakan bangunan. Bangunan terkunci saat putaran di lingkaran besi ini mencapai puncaknya (setiap atap bambu saling menumpu).

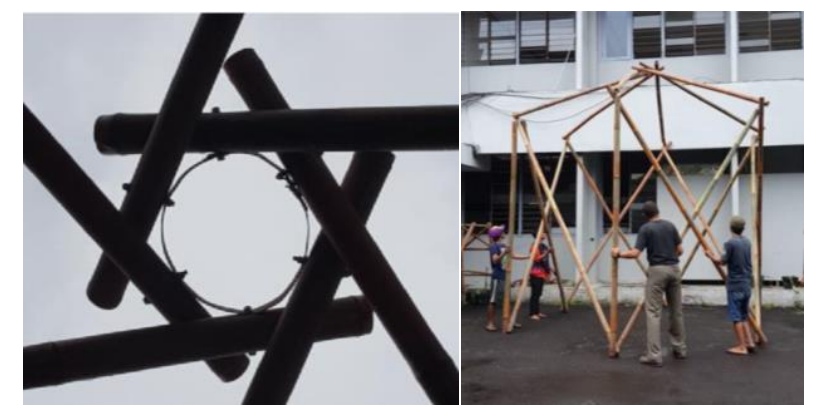

Figur 25 (kiri) Sambungan Atap Resiploy (kanan) Konfigurasi Terbuka Resiploy

(Sumber: Sudira, Bernadette. 2016. Eksplorasi Konstruksi Bambu Dengan Sistem Deployable. Skripsi Prodi Arsitektur. UNPAR)

Pada Rising Canes dari Penda, kemampuan duplikasi modul dicapai dengan sambungan antar bambu. Bambu yang ada diikat dengan ijuk. Sambungan yang digunakan ini dibuat pada setiap pertemuan modul. Modul yang ada pada bangunan ini merupakan kolom bambu 2 lantai yang membentuk ruang atas dan bawah. Jika dilihat lebih teliti, Rising Canes dari Penda sebenarnya memanfaatkan sistem resiprokal pada sambungan di tiap modulnya, karena batang bambu yang ada saling menumpu satu sama lain dan kemudian diikat dengan ijuk.

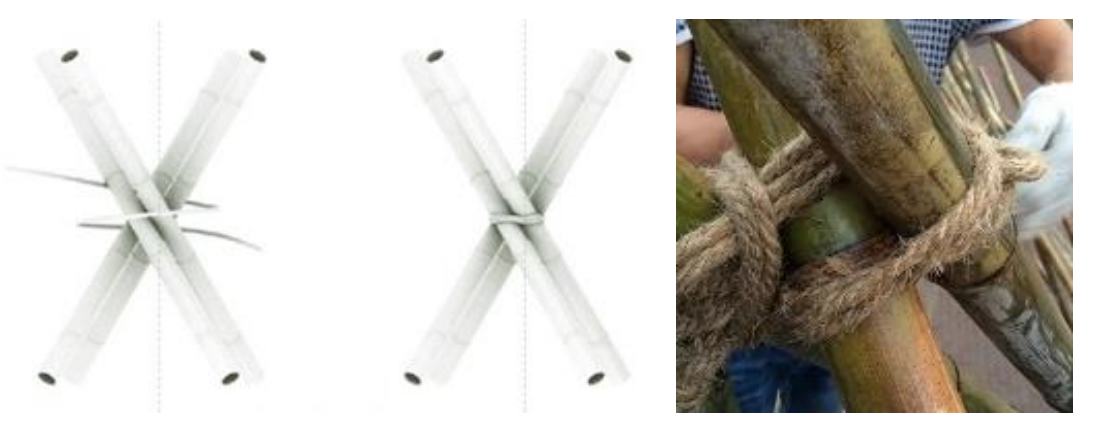

Figur 26 Sambungan pada Rising Canes

(Sumber: behance.com)

Melihat kedua bangunan tersebut, terdapat sebuah kesamaan yang dapat ditarik, yaitu kemampuan resiprokal yang diterapkan dalam kedua bangunan tersebut. Pada Resiploy, kemampuan resiprokal dimungkinkan dengan adanya sambungan lingkaran besi pada bagian atap bangunan, sedangkan pada Rising Canes, kemampuan resiprokal dimungkinkan dengan adanya sambungan ikatan ijuk pada setiap pertemuan bambu. Persamaan kedua bangunan yang terdapat pada sambungannya ini selanjutnya digabung menjadi sebuah sistem sambungan baru.

\subsection{EKSPLORASI DENGAN MAKET}

Mengingat Resiploy berbentuk segi enam, sedangkan Rising Canes berbentuk segi empat, maka penyederhanaan sambungan pun cukup mudah untuk dilakukan. Lingkaran besi 
yang awalnya terdapat 6 titik sambungan dibuat menjadi 4 titik sambungan hingga akhirnya diambil keputusan untuk membuat sambungan besi berbentuk tambah $(+)$ yang dapat memiliki 4 titik sambungan. Sambungan ini dibuat dengan cara menyambungkan 2 batang as drat menjadi bentuk tambah (+) dengan cara dilas.

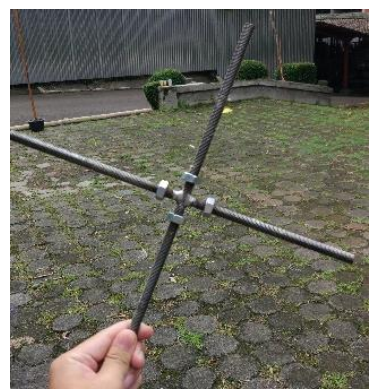

Figur 27 Sambungan Besi Tambah (+)

Sambungan berbentuk tambah (+) ini kemudian diuji dalam maket tanpa skala untuk melihat kemampuan resiprokal dan deployable-nya. Maket yang dibuat ternyata dapat menopang satu sama lain, dan juga dapat dilipat menjadi konfigurasi tertutup. Maket yang dibuat ini menjadi modul terkecil dari bagian perancangan struktur dalam skripsi ini.

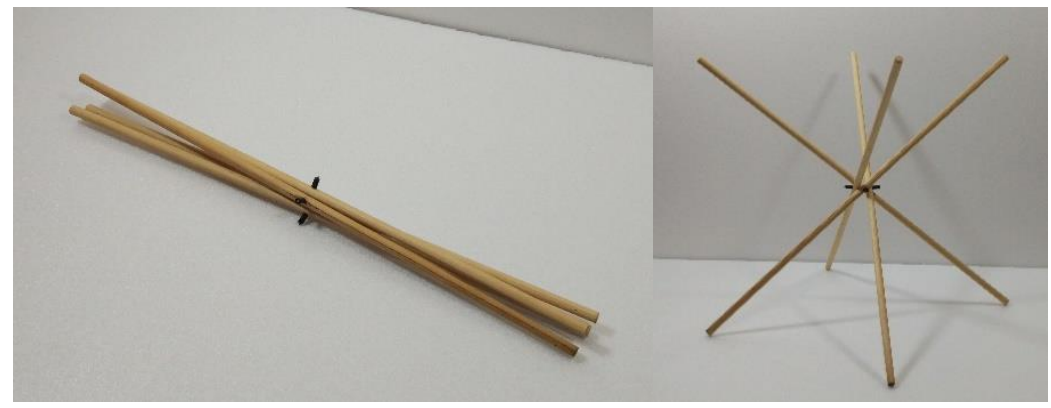

Figur 28 Percobaan Modul Terkecil

Modul yang telah dirancang ini kemudian dikembangkan lagi agar dapat diduplikasi ke berbagai arah seperti pada Rising Canes. Beberapa maket dibuat untuk melihat kemampuan duplikasi dari modul ini. Awalnya, modul diperkecil dengan memotong bagian atasnya sehingga menjadi 1 lantai seperti tenda, kemudian dengan sambungan yang sama, yaitu besi berbentuk tambah (+), modul tersebut disambungkan dengan modul lain dalam 2 arah, yaitu axis x dan y. Dengan sambungan yang sama tersebut, modul dapat diduplikasi ke dua axis, meskipun pada bagian samping bangunan, sambungan tidak dimanfaatkan dengan sempurna karena yang digunakan hanya 2 titik sambungan dari 4 titik yang tersedia.

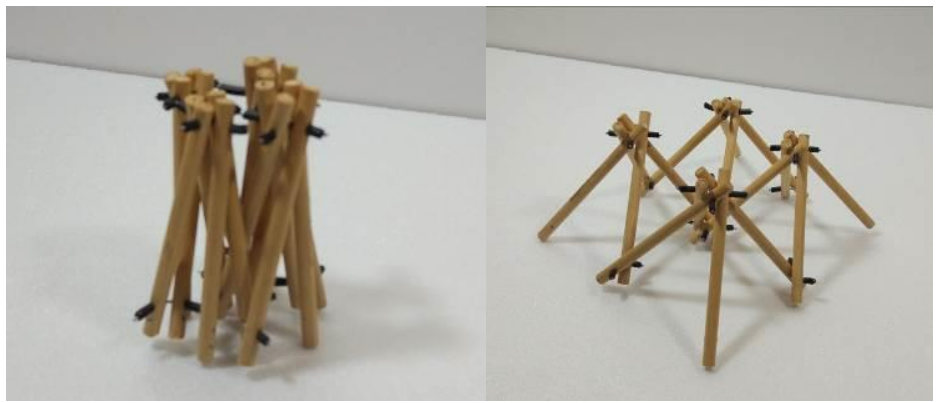

Figur 29 Percobaan Duplikasi 2 Arah 
Setelah berhasil dengan 2 axis, penulis berpendapat bahwa modul ini dapat diduplikasi ke axis $\mathrm{z}$ dengan menggunakan sistem sambungan yang sama. Rasa penasaran ini dibuktikan dengan menggunakan maket tanpa skala, namun kali ini modul tidak dipotong agar dapat melihat kemungkinan dupliaksi ke axis z. Modul awal diduplikasi ke 2 axis dengan menggunakan sistem sambungan yang sama, yaitu sambungan besi berbentuk tambah (+). Sistem sambungan ini ternyata masih dapat digunakan untuk menyambungkan bagian atas dari maket. Sama dengan maket pertama, pada bagian ujung samping maket, hanya 2 titik sambungan yang digunakan dari 4 titik yang tersedia. Hal ini dapat diakali dengan menggunakan sambungan lain yang berbentuk L karena hanya diperlukan 2 titik sambungan pada ujung samping maket.

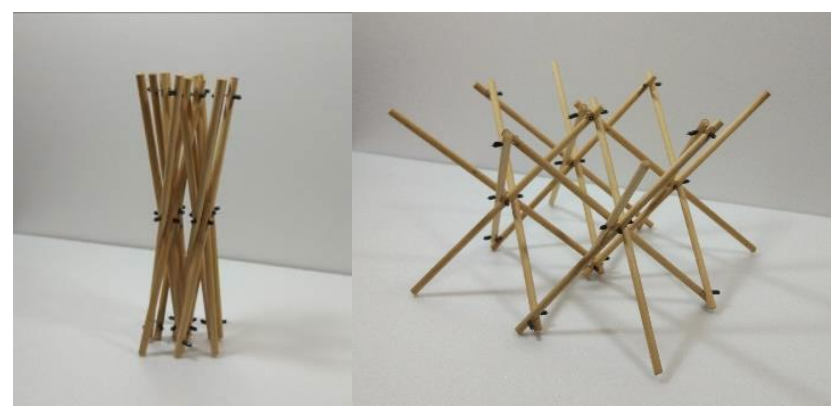

Figur 30 Percobaan Duplikasi 3 Arah

Konstruksi maket berskala 1:2 ini dilakukan di Kampus UNPAR. Konstruksi dilakukan untuk melihat kemungkinan yang terjadi di lapangan jika bangunan dibangun dengan ukuran yang pas. Konstruksi maket ini dikerjakan oleh 2 orang ahli yang terbiasa membangun dengan material bambu. Waktu yang dibutuhkan untuk penyelesaian adalah 3 hari, dikarenakan adanya kendala pada hari - hari awal. Namun, jika dijumlahkan, waktu optimal pembuatan bangunan in adalah sekitar 6 jam dengan pembagian sebagai berikut: Persiapan bambu (memotong dan mencuci) 3 jam, melubangi 3 titik pada bambu 1 jam, dan pemasangan bambu 2 jam.

Berikut ini adalah proses konstruksi dari maket berskala 1:2:

1. Mempersiapkan bambu yang akan digunakan, meliputi pemotongan bambu menjadi $3 \mathrm{~m}$, dan pencucian bambu untuk mencegah timbulnya rayap pada bambu

2. Memberi lubang pada bambu yang akan dipakai. Lubang yang dibuat adahal pada bagian tengah bambu, dan samping bambu (15 cm di kiri dan kanan). Lubang yang dibuat ini sejajar satu dengan lainnya.

3. Membuat 4 modul kecil bambu dengan sambungan besi tambah (+).

4. Menggabung 2 modul kecil terlebih dahulu

5. Menyambung modul kecil ketiga

6. Menyambung modul kecil keempat hingga menjadi bangunan pada maket yang telah dibuat sebelumnya.

\subsection{KOMPARASI RANCANGAN DENGAN OBJEK STUDI}

Modul struktur pada Resiploy, Prisma Segitiga, Rising Canes, Y-BIO, dan deployable/modular memanfaatkan bentuk yang cenderung sederhana. Dari bentuk sederhana ini, perancang dapat melakukan eksperimentasi dengan membuat selubung bangunan hingga menjadi bangunan layak pakai

Portabilitas dan transportabilitas modul struktur ditentukan oleh sambungan yang ada pada modul struktur. Untuk menghasilkan modul yang portabel, dibutuhkan adanya gerakan pada elemen modul. Resiploy, Prisma segitiga, dan hasil rancangan 
deployable/modular mampu di deploy karena adanya sambungan mur baut yang memungkinkan pergerakan pada bambu, sehingga bambu dapat terlipat untuk dibawa dengan mudah.

Duplikasi modul tidak dapat terjadi pada Resiploy dikarenakan tidak adanya sambungan yang mendukung, sedangkan Prisma Segitiga, Rising Canes, Y-BIO, dan deployable/modular dapat diduplikasi berkat sambungan yang terdapat pada masing-masing struktur. Sambungan untuk duplikasi merupakan sambungan sederhana yang terus diulang pada tiap pertemuan modul.

Stabilitas modul pada Resiploy dapat tercapai berkat adanya sistem penguncian mandiri dengan sambungan lingkaran besi pada atap yang menghasilkan struktur resiprokal. Pada Prisma Segitiga dan Rising Canes, stabilitas modul dicapai dengan bantuan elemen pengaku. Sedangkan pada deployable/modular, stabilitas modul dicapai berkat sambungan tambah (+) yang mengakibatkan seluruh komponen struktur saling menumpu satu sama lain, sama seperti atap Resiploy.

Semakin beragam sambungan yang digunakan akan semakin sulit juga pembuatan masal suatu struktur tersebut. Resiploy dan Prisma Segitiga memanfaatkan 2 jenis sambungan yang serupa dalam pembuatannya. Sambungan lingkaran besi pada Resiploy dan sambungan segitiga besi pada Prisma Segitiga membuat sulitnya bangunan ini untuk dibuat secara darurat. Sambungan pada Rising Canes, Y-BIO dan deployable/modular hanya 1 dan diulang terus pada tiap pertemuan modul, hal ini membuat pembuatan sturktur tersebut mudahdibuat dan dapat dibuat secara darurat dengan cepat.

Pondasi tidak dibutuhkan untuk setiap bangunan dikarenakan terdapat cukup penopang yang menempel tanah dari setiap bangunan. Lokasi penopang inipun menentukan kebutuhan pondasi. Pondasi dapat ditambahkan untuk menambah kekuatan dari bangunan, atau jika dihadapkan pada kondisi alas tertentu.

Pada deployable/modular, penambahan pondasi pada struktur akan membuat struktur kehilangan kemampuan untuk dapat dilipat, sehingga penggunaan pondasi hanya dilakukan ketika membutuhkan struktur permanen.

\section{KESIMPULAN}

Berdasarkan penelitian yang telah dilakukan, dapat diambil kesimpulan bahwa dalam bangunan deployable adalah dibutuhkan sambungan yang memungkinkan terjadinya gerakan pada elemen bangunan. Hal ini ditunjukan dalam objek studi. Pada Resiploy terdapat sambungan lingkaran besi pada atap bangunan yang membuat elemen atap dapat bergerak pada porosnya, dan sambungan pada badan bangunan berupa scissor like element yang mengakibatkan bangunan dapat terlipat. Sedangkan pada Prisma Segitiga terdapat sambungan besi segitiga pada pertemuan sudut bambu yang membuat bambu dapat bergerak pada porosnya, dan sambungan pada bagian tengah bambu berupa scissor like element yang memungkinkan terjadinya lipatan pada Prisma Segitiga.

Dalam merancang bangunan modular, dibutuhkan sambungan sederhana yang dapat direpetisi di setiap pertemuan elemen bangunan. Pada Rising Canes, dimanfaatkan sambungan berupa ikatan ijuk sederhana yang diimplementasikan di setiap pertemuan bambu. Sedangkan pada Y-BIO ikatan sederhana juga diimplementasikan di setiap pertemuan batang besi untuk menghasilkan bentuk yang diinginkan. Pengulangan sambungan inilah yang memungkinkan terjadinya duplikasi ke berbagai arah pada tiap objek studi.

Dengan melihat kedua sistem diatas, didapatkan kriteria yang dibutuhkan untuk membuat struktur bambu modular dengan sistem konstruksi deployable. Kriteria tersebut adalah dibutuhkannya sambungan yang dapat membuat elemen bangunan bergerak (memiliki 
poros putaran) agar mampu di-deploy, pengulangan sambungan di tiap pertemuan elemen agar dapat diduplikasi, dan merupakan struktur resiprokal agar dalam bangunan terdapat sistem penguncian mandiri.

Dengan melihat kriteria yang ada, diplihlah sistem sambungan pada Resiploy dan Rising Canes yang dirasa penting untuk perancangan struktur bambu modular dengan sistem konstruksi deployable. Pada Resiploy, sambungan besi lingkaran pada atap bangunan disederhanakan untuk dapat memenuhi kriteria rancangan. Sedangkan pada Rising Canes, bentuk dan sistem sambungan bangunan tersebut dimanfaatkan untuk memenuhi kriteria rancangan.

Sambungan atap Resiploy disederhanakan hingga menjadi sambungan besi berbentuk tambah (+) yang digunakan untuk menyambungkan pertemuan bambu pada bangunan Rising Canes. Dari sinilah tercipta sistem struktur baru yang dapat di deploy, repetisi, dan memanfaatkan sistem penguncian mandiri. Bangunan yang tercipta dapat dibuat dalam waktu 2 hari dengan waktu pelipatan kurang dari 1 menit

Lewat penelitian yang telah dilakukan, penulis mengharapkan adanya pengembangan struktur. Pengembangan ini dapat berupa perancangan atap, dinding, lantai, maupun hal lainnya untuk membuat bangunan ini menjadi bangunan yang utuh dapat digunakan oleh orang banyak. Selain itu, pengembangan juga dapat dilakukan dengan memperjelas kemampuan repetisi axis z yang belum sempurna.

\section{DAFTAR PUSTAKA}

Akgün, Yenal. (2010). A Novel Transformation Model for Deployable Scissor-Hinge Structures. Jerman: Universität Stuttgart.

Cendana, Fabianto (2017). Substitusi Ram Kawat Pada Struktur Cangkang Tipis Berbentuk Hyperbolic Paraboloid Konstruksi Ferosemen Dengan Kerangka Bambu. Skripsi tidak diterbitkan. Bandung: Universitas Katolik Parahyangan.

Hafid, Ahmad Nur. 2011. Modul Konstruksi Bambu.

Larsen, Olga Popovic. 2008. Reciproal Frame Arhitectural. Burlington:Eksevier Ltd.

Maurina, A., Budianastas, P., \& Carissa. (2017). Eksplorasi Struktur Bambu Dengan Konstruksi 'Deployable'. Bandung: Universitas Katolik Parahyangan

Raj, Dhenesh, Bindu Agarwal. 2014. Bamboo as Building Material.

Sudira, Bernadette. (2016). Eksplorasi Konstruksi Bambu Dengan Sistem Deployable. Skripsi tidak diterbitkan. Bandung: Universitas Katolik Parahyangan.

SUSAM, Gözde. (2013). A Research On A Reconfigurable Hypar Structure For Architectural Applications. Turki: Izimir Institue of Technology. 